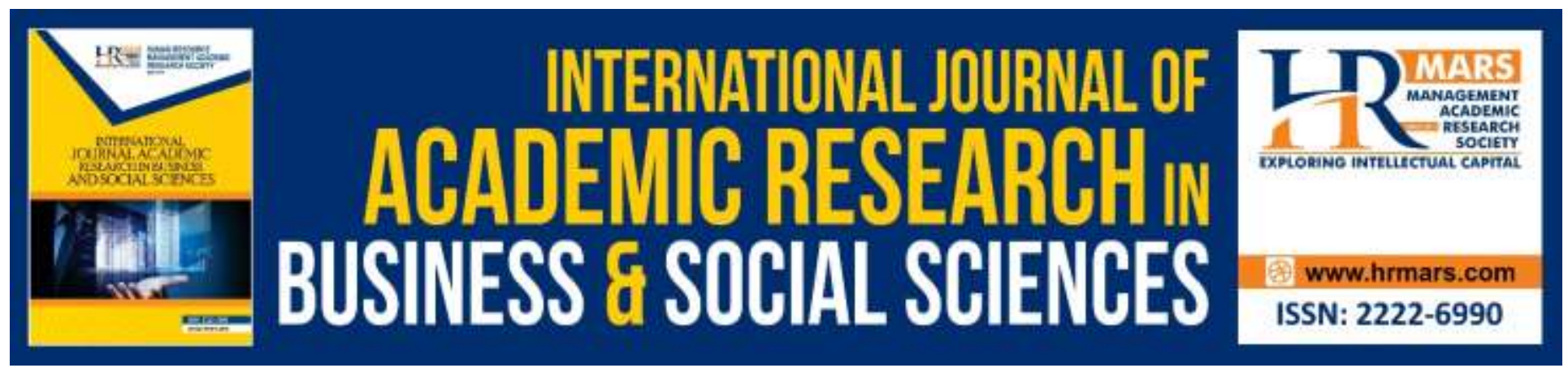

\title{
The Relationships Between Achievement Goal, Teacher Instructional Practices and Students' Academic Achievement
}

Amirah Mohd Juned, Faizah Abd. Majid, Sharifah Muzlia Syed Mustafa

To Link this Article: http://dx.doi.org/10.6007/IJARBSS/v9-i13/7000

DOI:10.6007/IJARBSS/v9-i13/7000

Received: 22 March 2019, Revised: 17 April 2019, Accepted: 02 May 2019

Published Online: 29 August 2019

In-Text Citation: (Juned et al., 2019)

To Cite this Article: Juned, A. M., Majid, F. A., \& Mustafa, S. M. S. (2019). The Relationships Between Achievement Goal, Teacher Instructional Practices and Students' Academic Achievement. International Journal of Academic Research in Business and Social Sciences, 9(13), 506-513.

Copyright: (C) 2019 The Author(s)

Published by Human Resource Management Academic Research Society (www.hrmars.com)

This article is published under the Creative Commons Attribution (CC BY 4.0) license. Anyone may reproduce, distribute, translate and create derivative works of this article (for both commercial and non-commercial purposes), subject to full attribution to the original publication and authors. The full terms of this license may be seen at: $\underline{\text { http://creativecommons.org/licences/by/4.0/legalcode }}$

Special Issue: Revolutionizing Education: Challenges, Innovation, Collaboration, 2019, Pg. 506 - 513 http://hrmars.com/index.php/pages/detail/IJARBSS JOURNAL HOMEPAGE

Full Terms \& Conditions of access and use can be found at http://hrmars.com/index.php/pages/detail/publication-ethics 


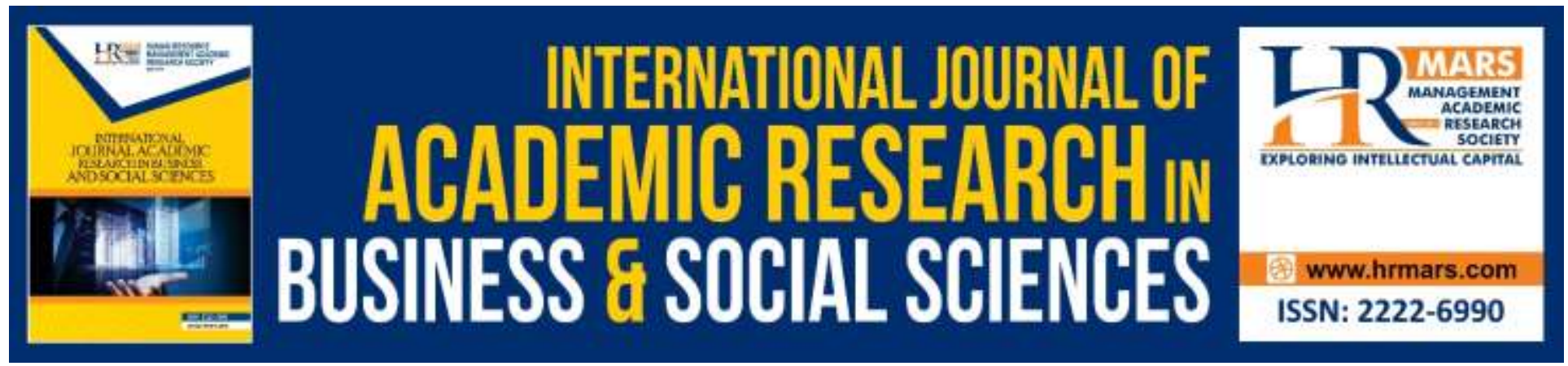

\title{
The Relationships Between Achievement Goal, Teacher Instructional Practices and Students' Academic Achievement
}

\author{
Amirah Mohd Juned, Faizah Abd. Majid, Sharifah Muzlia Syed \\ Mustafa \\ Faculty of Education, Universiti Teknologi MARA Cawangan Selangor, Malaysia
}

\begin{abstract}
Among the many factors contributing to the students' competency in learning are students' motivation and teacher instructional practices. Motivation is the internal state of an individual that arouses, directs and sustains behaviour. Achievement goal theory has been one of the most prominent theories of motivation in educational research for more than 25 years (Senko, Hulleman, \& Harackiewicz, 2011). It has been used in order to identify students' motivation and achievement- related behaviours. On the other hand, teacher instructional practices are one of the factors that could influence students' learning (Maulana, Opdenakker \& Bosker, 2016). Many studies have described that teaching practices are related to effective classroom learning and students' outcome (Mercer \& DeRosier, 2010). Different experts emphasised that different practices in teaching could efficiently move students forward in their learning. Therefore, this paper explores the relationships between students' achievement goals and academic achievement and also the possible moderation by teacher instructional practices. As this paper is driven by a concept paper approach, discussions on the findings are based on relevant literature review, which includes discussions on the theories and past research findings. A framework that signifies the possible relationship among the variables is provided. Keywords: Achievement Goals, Academic Achievement, Instructional Practice
\end{abstract}

\section{Introduction}

Education is a process of learning where there are interactions between students and educators. When a learning process is done efficiently, real learning situation will take place. In every learning process students will be tested by measuring their understanding on the subjects learned. Examination is one of the important aspects in measuring students' achievement at school (Rasul \& Bukhsh, 2011). The Ministry of Education in Malaysia has continuously monitored the performance of students through important examinations such as Ujian Penilaian Sekolah Rendah (UPSR), Pentaksiran Tingkatan 3 (PT3), and Sijil Pelajaran Malaysia (SPM). Each student will perform differently in the examination. Motivation has 
been identified as one of the most powerful determinants of students' success or failure in school (Hidi \& Harackiewicz, 2000). Students may have lots of reasons to succeed academically and achievement goal is one of the theories that are being used in identifying students' motivation and achievement-related behaviours. Other than students' motivation, teacher also plays an important role in determining students' behaviour in learning.

\section{Achievement Goal Theories}

Many psychologist and educators have considered that students' motivation as an important factor for successful school learning. Achievement goals are one of the prominent achievement motivation constructs in the last three decade (Wirthwein et al., 2013). It is considered to be relevant with students' behavior in an achievement because these goals determine their approach to, engagement in, and evaluation of performance in school learning (Fadlelmula, 2010). Achievement goals have focused on the two goal types which are mastery goal and performance goal. According to Elliot and McGroger (2001) mastery and performance goal is presumed to provide a different perceptual-cognitive framework in achievement setting whereby both goals show different pattern of process and outcome. Mastery goals have been identified beneficial because it focusses on the development of competence through task mastery, while performance goals are focused on the demonstration of competence relative to others. In explaining about mastery and performance goal, a contrast between approach and avoidance dimensions was added for both goals (Elliot \& McGregor, 2001). This distinction fundamentally bases upon whether students want to look competent or avoid looking incompetent at their schoolwork (Harackiewicz et al., 1998).

\section{Achievement Goal and Academic Achievement Outcome}

Recent literature reviews indicated that the evidence for the relationship between the goal orientations and academic achievement on the sample of middle and high school is mixed (Huang,2012; Wirthwein et al., 2013). The different outcome of students who hold different goals can be seen from the earlier study conducted by Dweck (1986) and Dweck and Leggett (1988). Children who are failed identified that mastery goal orientation has the intention to develop and enhance their competences in achievement-related situation and are able to cope with any difficulties. Contrary with children with performance goal orientation, they strive to be better than others and want to show their ability or strive to hide their incompetence. In details, there are some studies have come out with different outcome for the same goal achievement dimensions. The study on the mastery-approach goal and achievement shows positive relationship (Keys et al., 2012), differently with the study by Bipp and van Dam (2014) ; King and Mclnerney (2014) where they found that mastery-approach goals were not linked to achievement. 


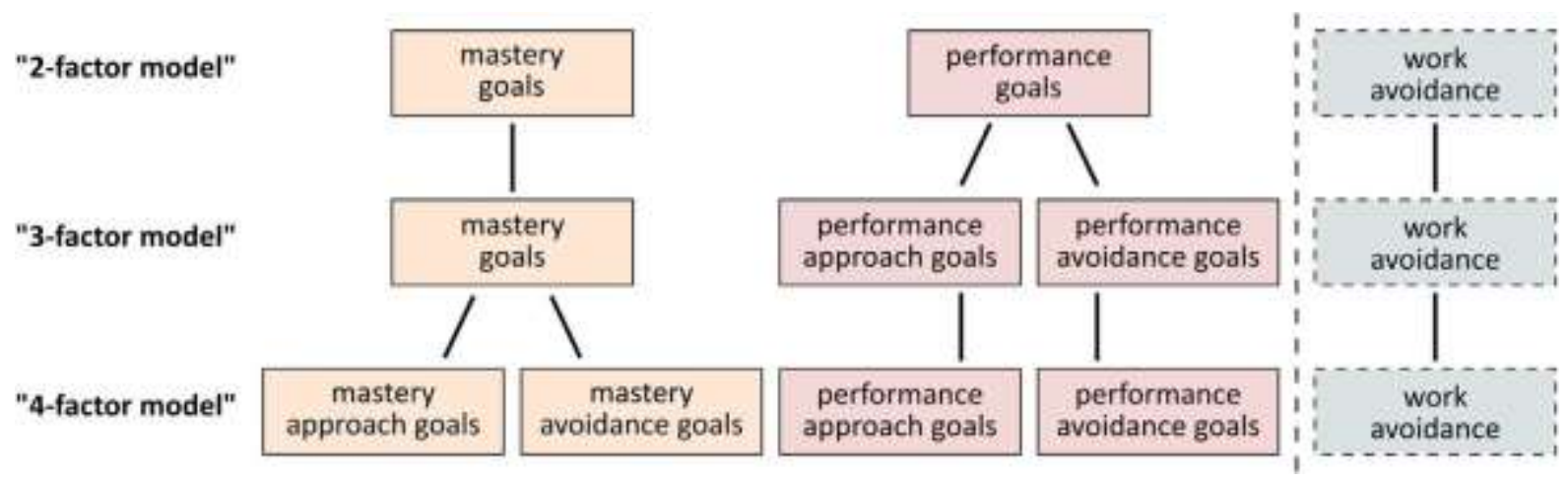

Figure 1: Achievement Goal Model 1

Different goal achievement is based on students' approach, engagement and responds in different achievement task and situation in a specific ways. Richardson et al., (2012) examined on the university students' GPA and found small correlation between achievement goals and GPA. Specifically, Harackiewicz et al. (2002b) found no association between GPA and the mastery-approach goals. Differently with the study conducted on the high school students where Wolters (2004) found a correlation between mastery-approach goals in Mathematics. Different goal achievement by university student and high school students are due to the different context of demand where university contexts are focus on (normative) evaluations (performance-oriented) and school contexts probably more supportive and focus on helping students developing new skills (mastery- oriented) (Linnenbrink-Garcia et al. (2008); Wirthwein et al., 2013). This indicates that the association between achievement goals and academic achievement might depend on the specific achievement criteria that are being investigated by the researcher. This has led to the prediction and understanding of different students' learning outcomes including learning strategies and engagement (Senko et al., 2011; Wigfield \& Cambria, 2010).

\section{Teacher Instructional Practices and Academic Achievement Outcome}

Teacher instructional practices are related to teachers' teaching style where the teachers express their preferences during instructional activities. Instructional practices comprise of manner, methods or means in which the teachers convey their information, and influence students' behaviour towards understanding and learning (Bota \& Tulbure, 2015). It also includes the teachers' role in the classroom. Teacher is one of the factors that could influence on students' learning because teacher who teaches effectively will benefits to the student (Lumpkin, 2010; Alzgool, 2019; Muhammad, Saoula, Issa \& Ahmed, 2019). According to Rashid et al., (2015), Malaysian government and employing authorities should focus on improving teaching practices because quality teacher with high-performing teachers can improve student achievement. Many studies have described that the aspects of teaching practice are related to effective classroom learning and students' outcome. Direct instruction such as the close monitoring, adequate pacing, classroom management, and clarity of presentation have shown a positive impact on student achievement (Zakharov et al., 2014; Khalid, Islam \& Ahmed, 2019). 
Past research has indicated that teacher motivation has effect on teacher instructional practices (Schiefele, Streblow, \& Retelsdorf, 2013). For example from the study conducted by Retelsdoft (2010) showed that, teachers with ability-approach goals and work avoidance were positive predictors of performance-oriented practices but negatively predicted on masteryoriented practices. Teachers who are motivated will work harder and put more effort in trying new technique and activities in order to help students to understand the learning.

There are several teacher instructional practices used by the teachers in the classroom which can influence on students' performance at school. Recent discussion on the school inputs in improving students' outcomes which focused on teacher showed that students with more effective teachers perform better during the achievement test (Zakharov et al., 2014). Based on the study conducted by Bota and Tulbure (2015), teacher who emphasised on the transmission of concrete contents and students' understanding of information have positive influence on the result of the examination. Other than that, Schwerdt and Wuppermann (2011) found that by changing time from problem solving to lecturing has resulted in an increase in students' achievement. Study conducted by Lavy (2011) showed that teacher who is masteryoriented have positive effects on students' test score whereby the teacher emphasizes on instilment of knowledge and comprehension. This shows that previous study have identified that teacher instructional practices could influence on the students' academic achievement.

The Relationship Between Achievement Goal And Students' Academic Achievement, Which Is Moderated By Teacher Instructional Practices.

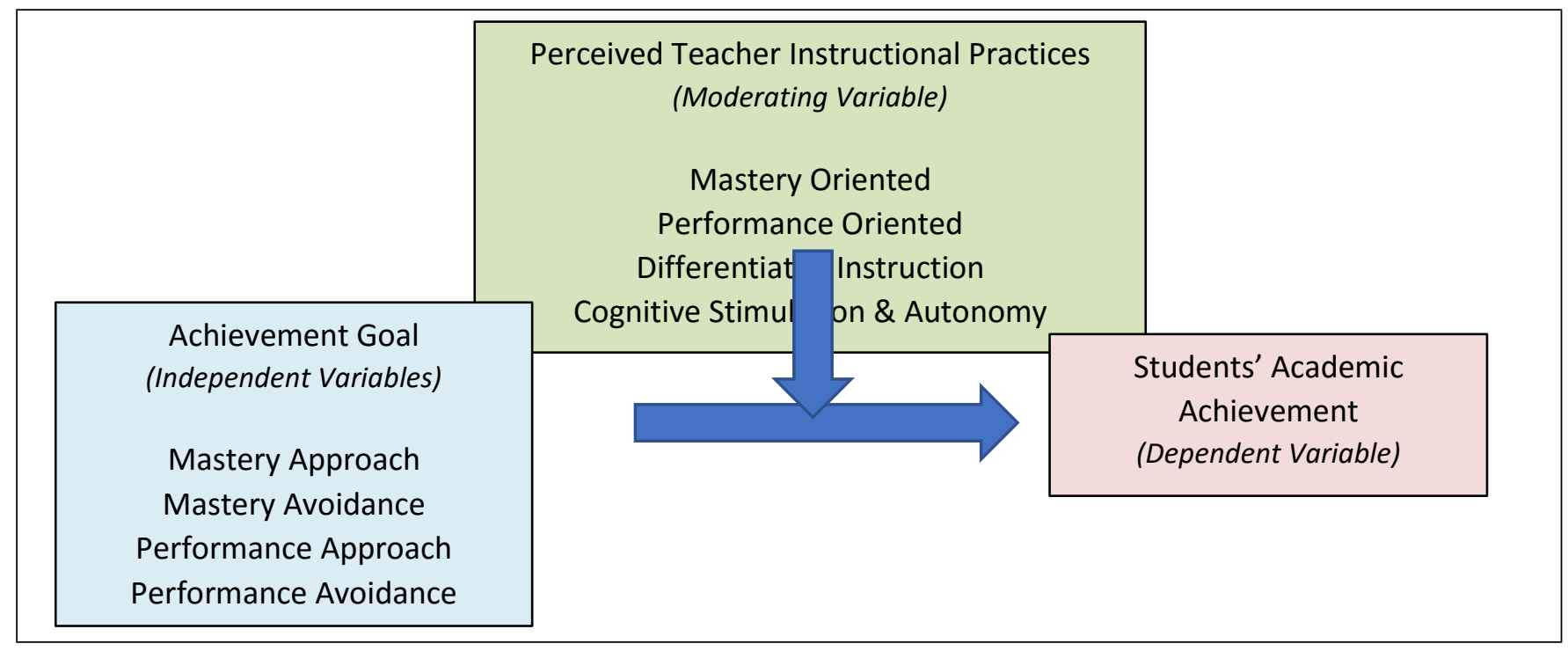

Figure 2: Proposed Conceptual Framework 1

Ine aım of this paper is to show the relationship between varıous dimensions of I he aım ine aim The aim The aim of this paper is to show the relationship between various dimensions of achievement goal theory on students' academic achievement which moderated by perceived teacher instructional practices. Four dimensions of achievement goal were identified; mastery- 
approach, mastery- avoidance, performance approach and performance-avoidance, in order to see how much these goal affects on students' academic achievement. Study by Keys, Conley, Duncan, \& Domina (2012) has shown the correlation between achievement goal and mathematics achievement. The findings confirmed the hypothesis where mastery approach has mild correlation with achievement. Meanwhile, there is no correlation between performance approach and achievement. Different outcome could be identified from the proposed framework as the present study will look at three different subjects for students' academic achievement. Students' English, Mathematics and Science achievement will be used in identifying whether achievement goal can predict on students' academic achievement. It is very crucial to look at English, Mathematics and Science achievement because these three subjects are very significant subject to students' development.

Besides that, this study use students' perception on teacher instructional practices as a mediator. Ahmed and Aziz (2009) identified that students' perception of their teacher's teaching could contribute in improving the teaching and learning of the teacher as it gives fruitful suggestions for the teachers' future improvement. Other than that, students' perception of teachers' practices in the classroom is an important factor for students' motivation and engagement in learning. The proposed conceptual framework is based on the past research and theoretical consideration. It is predicted that students' achievement goal will influence on the students' perception on teacher instructional practices which in turn affects students' academic performance.

\section{Conclusion}

The present study will identify the influence of students' achievement goal and perceived instructional practices on students' academic achievement. Academic goals have been identified as one of the most influential predictors of students' successes or failures (Hidi \& Harackiewicz, 2000). Besides students' academic goals, instructors' instructional practices could also influence the students' academic achievement (Lumpkin, 2010). Nonetheless, although it is commonly accepted that students' academic goals and instructors' instructional practices are important aspects that could influence students' academic achievement, there is yet a welldefined descriptors for the best instructional practices based on an empirical research on students' academic goals. Hence, the present study is conducted to determine the relationship between students' achievement goals and perceived instructors' instructional practices and their possible effects on students' achievements. The outcomes of the present study will help teachers and instructors of all levels alike to know thier students better in terms of their academic goals and assess how their own instructional practices could have affected their students' academic performance. Besides that, the instruments used for this study can be used by teachers and instructors of any level of education as an inventory or checklist in determining how their students' achievement goals and their perceived instructional practices could facilitate the students' academic achievement. Most importantly, the findings from the present study could help develop a potential instructional model that leverages students' academic achievements based on their academic goals and their perceived instructors' instructional practices. 


\section{Acknowledgement}

Special thanks to Institute of Research Management \& Innovation, IRMI for funding this work through GIP Gran No. 600-IRMI 5/3/GIP.

\section{References}

Alzgool, M. (2019). Nexus between Green HRM and Green Management towards Fostering Green Values. Management Science Letters, 9(12), 2073-2082.

Bipp, T., \& van Dam, K. (2014). Extending hierarchical achievement motivation models: The role of motivational needs for achievement goals and academic performance. Personality and Individual Differences, 64, 157-162.

Bota, O. A., \& Tulbure, C. (2015). Aspects Regarding the Relationship Between Teaching Styles and School Results. Procedia - Social and Behavioral Sciences (pp. 285 - 290). Elsevier Ltd.

Dweck , C. (1986). Motivational Processes Affecting Learning. American Psychologist, 10401048. Dweck, C., \& Leggett, E. (1988). A Social-Cognitive Approach To Motivation And Personality. Psychological Review, 256-273.

Elliot, A. J., \& McGroger, H. A. (2001). A 2 X 2 Achievement Goal Framework. Journal Personality and Social Psychology, 501-519.

Fadlelmula, F. K. (2010). Educational Motivation andStudents' Achievement Goal Orientations. Social and Behavioral Sciences, (pp. 859-863).

Harackiewicz, J. M., Barron, K. E., Tauer, J. M., \& Elliot, A. J. (2002b). Predicting success in college: A longitudinal study of achievement goals and ability measures as predictors of interest and performance from freshman year through graduation. Journal of Educational Psychology, 94, 562-575.

Hidi, S., \& Harackiewicz, J. (2000). Motivating The Academically Unmotivated: A Critical Issue for The 21st Century. Review of Educational Research , 151-179.

Huang, C. (2012). Discriminant and criterion-related validity of achievement goals in predicting academic achievement: A meta-analysis. Journal of Educational Psychology, 48-73.

Keys, T. D., Conley, A. M. M., Duncan, G. J., \& Domina, T. (2012). The role of goal orientations for adolescent mathematics achievement. Contemporary Educational Psychology, 37(1), 47-54. https://doi.org/10.1016/j.cedpsych.2011.09.002

King, R. B., \& McInerney, D. M. (2014). The work avoidance goal construct: Examining its structure, antecedents, and consequences. Contemporary Educational Psychology, 39, 42-58.

Khalid, N., Islam, D. M. Z., \& Ahmed, M. R. M. (2019). Sentrepreneurial Training and Organizational Performance: Implications for Future. Humanities \& Social Sciences Reviews, 7(2), 590-593.

Linnenbrink-Garcia, L., Tyson, D. F., \& Patall, E. A. (2008). When are achievement goal orientations beneficial for academic achievement? A closer look at main effects and moderating factors. International Review of Social Psychology, 21, 19-70.

Lumpkin, A. (2010). 10 School-Based Strategies for Student Success. Kappa Delta Pi Record, 7175. 
Maulana, R., Opdenakker, M. C., \& Bosker, R. (2016). Teachers' instructional behaviors as important predictors of academic motivation: Changes and links across the school year. Learning and Individual Differences, 147-156.

Mercer, S. H., \& Derosier, M. E. (2010). A Prospective Investigation of Teacher Preference and Children's Perceptions of The Student-Teacher Relationship. Psychology in the Schools, 184-192.

Muhammad, K., Saoula, O., Issa, M., \& Ahmed, U. (2019). Contract Management and Performance Characteristics: An Empirical and Managerial Implication for Indonesia. Management Science Letters, 9(8), 1289-1298.

Rasul, S., \& Bukhsh, Q. (2011). A study of factors affecting students' performance in examination at university level. Procedia Social and Behavioral Sciences (pp. 2042-2047). Elsevier Ltd.

Retelsdorf, J., Butler, R., Streblow, L., \& Schiefele, U. (2010). Teachers' Goal Orientations for Teaching: Associations With Instructional Practices, Interest in Teaching, and Burnout. Learning and Instruction, 30-46.

Richardson, M., Abraham, C., \& Bond, R. (2012). Psychological correlates of university students' academic performance: A systematic review and meta-analysis. Psychological Bulletin, 138, 353-387.

Schiefele, U., Streblow, L., \& Retelsdorf, J. (2013). Dimensions of teacher interest and their relations to occupational well-being and instructional practices. Journal for Educational Research Online, 7-37.

Senko, C., Hulleman, C., \& Harackiewicz, J. (2011). Achievement Goal Theory at the Crossroads: Old Controversies, Current Challenges, and New Directions. Journal Educational Psychologist , 26-47.

Wigfield, A., \& Cambria, J. (2010). Students' achievement values, goal orientations, and interest: Definitions, development, and relations to achievement outcomes. Developmental Review, 30, 1-35.

Wirthwein, L., Sparfeldt, J. R., Pinquart, M., Wegerer, J., \& Steinmayr, R. (2013). Achievement Goals And Academic Achievement: A Closer Look. Educational Research Review 10, 6689.

Wolters, C. A. (2004). Advancing achievement goal theory: Using goal structures and goal orientations to predict student's motivation, cognition, and achievement. Journal of Educational Psychology, 96, 236-250.

Zakharov , A., Carnoy, M., \& Loyalka, P. (2014). Which teaching practices improve student performance on high-stakes exams? Evidence from Russia. International Journal of Educational Development, 13-21. 